Ryan Satya Jorgi ${ }^{*}$, Siwi Gayatri, Tutik Dalmiyatun

Program Studi Agribisnis, Fakultas Peternakan dan Pertanian, Universitas

Diponegoro Semarang

*)Email korespondensi: ryanjorgi28@gmail.com
AGRARIS: Journal of Agribusiness and Rural Development Research

Vol. 5 No. 2 Juli-Desember 2019

\section{Hubungan Tingkat Pengetahuan Petani dengan Efektivitas Pelaksanaan Program Kartu Tani di Kabupaten Semarang}

\author{
Relationship Between the Level of Farmer \\ Knowledge and the Effectiveness of Farmer Card \\ Program (Program Kartu Tani) Implementation in \\ Semarang Regency
}

DOI: http://dx.doi.org/10.18196/agr. 5278

\begin{abstract}
This research was motivated by the policies of the Central Java provincial government in overcoming the problem of distributing subsidized fertilizers through the farm card program, which in the implementation still had problems, especially at the farmer level. The study aimed to describe the implementation of Farmer Card Program (Program Kartu Tani) and to analyse the relationship between knowledge level of farmers and the effectiveness of Farmer Card Program (Program Kartu Tani) in Semarang Regency. This research was conducted from February to May 2018. Survey method was used in this study. Multistage random sampling method was used for determining respondents. Data collection was done by interview using a questionnaire. Data analysis were descriptive analysis and Rank Spearman correlation analysis using SPSS. This research showed the level of farmers knowledge about Farmer Card Program (Program Kartu Tani) was in the category of knowless. The level of effectiveness about implementation of the Farmer Card Program (Program Kartu Tani) was in the effective category. While the implementation of Farmer Card Program (Program Kartu Tani) at farmer level was effective because of the role farmer group in
\end{abstract}

implementing program assisted by extension agent and related government institution although there were still face some obstacles that need to be improved to increase effectivity of farmer card implementation. There was a strong and significant relationship between the knowledge level and effectiveness of the Farmer Card Program (Program Kartu Tani), with the coefficient number 0.568 .

Keywords: Effectiveness, Farmer Card Program (Program Kartu Tani), Fertilizer, Implementation, Knowledge.

\section{INTISARI}

Penelitian ini dilatarbelakangi kebijakan pemerintah Provinsi Jawa Tengah dalam mengatasi permasalahan penyaluran pupuk bersubsidi melalui program kartu tani, yang dalam pelaksanaannya masih terdapat kendala, khususnya di tingkat petani. Penelitian ini bertujuan untuk menggambarkan pelaksanaan program kartu tani dan mengungkap hubungan tingkat pengetahuan petani dengan efektivitas program kartu tani di Kabupaten Semarang. Penelitian dilaksanakan pada bulan Februari - Mei 2018 dengan menggunakan metode survey. Sampel petani dipilih menggunakan metode multistage random sampling. Pengumpulan data dilakukan dengan cara wawancara menggunakan kuesioner. Analisis data dilaksanakan menggunakan analisis deskriptif dan korelasi Rank Spearman. Hasil penelitian menunjukkan tingkat pengetahuan petani terhadap program kartu tani termasuk dalam kategori kurang tahu, sementara tingkat efektivitas pelaksanaan program kartu tani termasuk dalam kategori efektif. Pelaksanaan program kartu tani di tingkat petani berjalan efektif dikarenakan adanya peran kelompok tani dalam pelaksanaan program dengan dibantu penyuluh dan instiansi terkait. Terdapat hubungan yang signifikan antara tingkat pengetahuan petani dengan efektivitas pelaksanaan program kartu tani, dengan koefisien korelasi sebesar 0,568.

Kata kunci: Efektivitas, Kartu tani, Pelaksanaan program, Pupuk bersubsidi, Pengetahuan. 


\section{PENDAHULUAN}

Pupuk merupakan sarana produksi yang memiliki peran strategis dalam mendukung sektor pertanian sebagai upaya untuk meningkatkan hasil produksi petani. Pemberian pupuk pada tanaman dapat mempercepat pertumbuhan dan meningkatkan produksi (Widarti, 2016). Penggunaan pupuk yang diarahkan pada penerapan pupuk berimbang dan organik sesuai rekomendasi, perlu didukung akses dalam memperoleh pupuk dengan harga yang terjangkau (Kementerian Pertanian, 2017).

Dalam upaya mengontrol peredaran pupuk dan kemudahan petani mengakses pupuk, pemerintah membuat kebijakan penyediaan pupuk bagi petani melalui subsidi harga pupuk. Pupuk bersubsidi merupakan pupuk yang pengadaan dan penyalurannya mendapat subsidi dari pemerintah. Program ini dilaksanakan untuk memenuhi kebutuhan petani terhadap pupuk dengan harga yang terjangkau. Adapun jenis pupuk yang mendapat subsidi meliputi Urea, SP-36, ZA, NPK Phonska dan pupuk organik (Peraturan Menteri Perdagangan, 2013). Kebijakan subsidi dan distribusi pupuk telah diterapkan pemerintah yaitu mulai dari tahap perencanaan kebutuhan, penetapan harga eceran tertinggi (HET) dan besaran subsidi serta sistem distribusi ke pengguna pupuk (Rachman dan Sudaryanto, 2010).

Penyediaan pupuk bersubsidi didasarkan pada rencana definitif kebutuhan kelompok (RDKK) yang merupakan kebutuhan riil petani untuk satu periode dalam pengelolaan usahatani, selanjutnya RDKK digunakan sebagai dasar dalam penyaluran pupuk bersubsidi di tingkat penyalur (Widarti, 2016). Penyusunan RDKK dilakukan oleh kelompok tani dengan dibantu oleh penyuluh lapangan.

Sebagai sebuah program dengan target yang sangat luas, implementasi subsidi pupuk menghadapi berbagai masalah dan kendala, yang mengakibatkan terjadinya penurunan efektivitas program. Permasalahan dan kendala yang dihadapi, antara lain: 1) penyelewengan distribusi pupuk bersubsidi; 2) kesenjangan antara ketersediaan dan kebutuhan; dan 3) terjadinya bias sasaran/target (Susila, 2010); serta 4) terjadinya penyaluran pupuk yang belum tepat sasaran, perembesan, kelangkaan pupuk, dan kenaikan harga di tingkat petani (Moko, 2017). Pemerintah Provinsi Jawa Tengah bekerjasama dengan Kementerian Pertanian dan Bank BRI membuat kebijakan agar distribusi pupuk bersubsidi dapat memenuhi asas 6 tepat (jumlah, jenis, waktu, tempat, mutu, dan harga) serta meminimalisir permasalahan dalam pengawasan, pengadaan dan penyaluran pupuk bersubsidi dengan menggunakan kartu tani (Biro Infrastuktur dan Sumberdaya Alam Provinsi Jawa Tengah, 2016).

Kartu tani merupakan sebuah alat yang digunakan petani untuk menebus pupuk bersubsidi. Selain itu, kartu tani dapat digunakan sebagai tabungan bagi petani, tarik tunai, belanja sehari-hari, pembayaran tagihan dan transfer antar bank. Untuk mendapatkan kartu tani petani harus tergabung dalam kelompok tani. Jenis dan jumlah pupuk subsidi yang diterima petani melalui kartu tani sesuai dengan luas lahan, komoditas dan jenis pupuk yang disusun melalui rencana definitif kebutuhan kelompok (RDKK) oleh penyuluh bersama petani yang kemudian di upload ke Sistem Informasi Manajemen Pangan Indonesia (SIMPI).

Efektivitas program merupakan pendekatan yang digunakan untuk melihat tercapai atau tidaknya tujuan program. Program dikatakan efektif apabila sasaran atau tujuan program tercapai sesuai dengan yang telah ditetapkan. Subsidi pupuk dikatakan berhasil apabila masyarakat menerima manfaat dari subsidi pupuk untuk meringankan beban penyediaan dan penggunaan pupuk dalam menjalankan kegiatan usahataninya (Arisandi, 2016). Efektivitas program dapat dilihat dari: 1) tercapainya tujuan kebijakan; 2) tercapainya sasaran kebijakan; 3) ketepatan waktu pelaksanaan; 4) komunikasi berkenaan dengan bagaimana kebijakan disosialisasikan; 5) ketersediaan sumber daya untuk melaksanakan kebijakan; 6) sikap dan tanggap dari para pihak yang terlibat; dan 7) bagaimana struktur organisasi pelaksana kebijakan (Yuliani, 2015).

Program kartu tani di Provinsi Jawa Tengah diinisiasi pada tahun 2016, tetapi baru serentak dilaksanakan pada awal tahun 2018. Hal tersebut terjadi karena pelaksanaan dan penggunaan kartu 
tani, khususnya di tingkat petani, masih ditemukan banyak kendala di lapangan, serta ditemukan beberapa penolakan di berbagai daerah. Kabupaten Semarang merupakan salah satu wilayah di Provinsi Jawa Tengah yang sudah menjalankan program kartu tani secara serentak per Januari 2018.

Hingga saat ini belum ada penelitian yang relevan tentang kartu tani sehingga sangat perlu dilakukan penelitian tentang pelaksanaan program kartu tani. Hal ini penting dikarenakan kartu tani sebagai kebijakan pemerintah Provinsi Jawa Tengah untuk alat penebusan pupuk bersubsidi diharapkan efektif dalam proses pelaksanaanya. Program ini ditujukan kepada petani yang sebagian besar memiliki latar belakang pendidikan rendah dengan kemampuan mengaplikasikan teknologi yang terbatas. Keberhasilan dari program ini didukung oleh pengetahuan petani dalam menggunakan kartu tani. Pengetahuan petani diduga dapat meningkatkan efektivitas pelaksanaan program kartu tani. Oleh karena itu penelitian terkait kartu tani perlu direview lebih lanjut. Informasi ini penting, mengingat kartu tani merupakan program yang relatif baru, sehingga masih memerlukan berbagai penyempurnaan untuk implementasi yang lebih luas di masa mendatang. Tulisan ini bertujuan untuk menggambarkan pelaksanaan program kartu tani di Kabupaten Semarang, dan mengungkap hubungan tingkat pengatahuan dengan efektivitas program. Manfaat dari penelitian ini adalah untuk memberikan informasi sebagai bahan kajian untuk evaluasi pelaksanaan program kartu tani Jawa Tengah sebagai salah satu kebijakan pemerintah daerah maupun pusat dan dapat menjadi referensi untuk penelitian terkait.

\section{METODE PENELITIAN}

Survei dilaksanakan pada bulan Februari Mei 2018 di enam kecamatan di Kabupaten Semarang yang terpilih sebagai sampel. Sampel petani dipilih menggunakan teknik stratified random sampling dengan cara mengelompokkan kecamatan di Kabupaten Semarang berdasarkan jumlah petani menjadi 3 kategori, yaitu kepadatan tinggi ( $>6.000$ petani), kepadatan sedang (4.000-6.000 petani) dan kepadatan rendah $(<4.000$ petani). Dari setiap kategori diambil dua kecamatan secara random, yakni: Kecamatan Sumowono dan Kecamatan Getasan dari kategori kepadatan tinggi, Kecamatan Banyubiru dan Kecamatan Bawen dari kepadatan sedang, Kecamatan Ungaran Timur dan Kecamatan Ambarawa dari kategori rendah. Selanjutnya dari setiap kecamatan dipilih secara random 2 kelompok tani, dan dari setiap kelompok tani dipilih 10 petani anggota kelompok secara random, sehingga secara keseluruhan penelitian ini melibatkan 120 petani sebagai responden. Pengumpulan data dilakukan dengan cara wawancara menggunakan kuesioner.

Pengetahuan petani (Var X) terhadap program kartu tani didefinsikan sebagai penguasaan informasi yang diterima petani dari sosialisasi program kartu tani yang telah dilaksanakan oleh penyuluh, dinas terkait dan Bank BRI. Indikator tingkat pengetahuan petani mencakup pengetahuan tentang aspek tujuan (terdiri atas 5 soal), ruang lingkup (terdiri atas 5 soal), struktur organisasi (terdiri atas 3 soal), manfaat (terdiri atas 4 soal), pedoman (terdiri atas 4 soal) dan tata cara penggunaan kartu tani (terdiri 4 soal), yang masingmasing diukur menggunakan skor dengan skala 5-1 (sangat tahu, tahu, kurang tahu, tidak tahu, sangat tidak tahu). Tingkat pengetahuan responden terhadap penggunaan kartu tani diukur dari skor total yang dikategorikan dalam tiga katagori, yakni tidak tahu untuk kisaran skor 25-57; kurang tahu untuk kisaran skor 58-90; dan tahu untuk kisaran skor 91-125.

Efektivitas (Var Y) dalam penelitian ini adalah kemampuan melaksanakan program tanpa adanya tekanan atau ketegangan. Efektivitas pelaksanaan program diukur dari indikator distribusi, pengendalian dan pengawasan pupuk bersubsidi sesuai dengan asas 6 tepat, yaitu : aspek tepat jumlah (terdiri atas 4 soal), tepat jenis (terdiri atas 3 soal), tepat tempat (terdiri atas 3 soal), tepat waktu (terdiri atas 3 soal), tepat mutu (terdiri atas 3 soal) dan tepat harga (terdiri atas 2 soal) yang masing-masing diukur menggunakan skor dengan skala 5-1 (sangat setuju, setuju, netral, tidak setuju, sangat tidak setuju). Tingkat efektivitas pelaksanaan program kartu tani diukur dari skor total yang dikategorikan dalam tiga kategori, yakni tidak efektif untuk kisaran skor 18-41; 
kurang efektif untuk kisaran skor 42-65; dan efektif untuk kisaran skor 66-90.

Pelaksanaan program kartu tani dianalisis secara deskriptif, sedangkan hubungan tingkat pengetahuan petani dengan efektivitas pelaksanaan program dianalisis menggunakan korelasi Rank Spearman (Siregar, 2017).

\section{HASIL DAN PEMBAHASAN IDENTITAS RESPONDEN}

Hasil analisis menunjukkan bahwa mayoritas petani yang terlibat dalam program kartu tani mempunyai karakteristik yang sama dengan petani pada umumnya, yakni berusia (21-60 tahun), berlatar belakang pendidikan Sekolah Dasar (SD), memiliki pengalaman bertani lebih dari 10 tahun, dan memiliki luas lahan sempit dengan luasan kurang dari $5000 \mathrm{~m}^{2}$ (Tabel 1).

TABEL 1. IDENTITAS RESPONDEN BERDASRKAN UMUR, PENDIDIKAN PENGALAMAN BERTANI DAN LUAS LAHAN

\begin{tabular}{lccc}
\hline Kategori & Indikator & $\begin{array}{c}\text { Jumlah } \\
\text { (Jiwa) }\end{array}$ & $\begin{array}{c}\text { Persentase } \\
(\%)\end{array}$ \\
\hline Umur & $21-30$ & 4 & 3 \\
& $31-40$ & 13 & 11 \\
& $41-50$ & 35 & 29 \\
& $51-60$ & 32 & 27 \\
& $61-70$ & 29 & 24 \\
Pendidikan & $>70$ & 7 & 6 \\
& SD & 74 & 62 \\
& SMP & 18 & 15 \\
Pengalaman bertani & SMA & 26 & 22 \\
& Perguruan Tinggi & 2 & 2 \\
Luas lahan & $1-5$ & 9 & 8 \\
& $6-10$ & 29 & 24 \\
& $>10$ & 82 & 68 \\
& $<5000 \mathrm{~m}^{2}$ & 61 & 51 \\
& $5000-10.000 \mathrm{~m}^{2}$ & 50 & 41 \\
& $>10.0000 \mathrm{~m}^{2}$ & 9 & 8 \\
\hline
\end{tabular}

Umur petani terkait dengan efektivitas pelaksanaan program kartu tani. Petani yang memiliki rentang usia produktif (21-60 tahun) cenderung mendukung adanya program kartu tani yang mempermudah penebusan pupuk bersubsidi dan dapat digunakan untuk transaksi perbankan; sedangkan petani berusia lanjut cenderung menolak program kartu tani karena petani merasa kesulitan menggunakan kartu tani dalam penebusan pupuk bersubsidi.
Tingkat pendidikan berpengaruh terhadap penerimaan inovasi, semakin tinggi tingkat pendidikan diharapkan pola berpikir semakin rasional. Terkait dengan pelaksanaan program kartu tani, petani bependidikan rendah cenderung mengalami kesulitan dalam pelaksanaan kartu tani sehingga perlu dibantu kelompok tani dan penyuluh. Sebaliknya, petani yang berpendidikan tinggi cenderung memiliki kemampuan yang lebih tinggi dalam melaksanakan program kartu tani secara mandiri.

Pengalaman mengelola usahatani berpengaruh terhadap pembentukan sikap petani terhadap inovasi atau program baru yang diperkenalkan pemerintah (Suharyanto, 2017). Terkait dengan pelaksanaan program kartu tani, petani yang memiliki pengalaman lebih dari 10 tahun cenderung kurang setuju dengan penggunaan kartu tani dan memilih untuk penebusan langsung. Petani merasa kesulitan dalam penebusan pupuk bersubsidi menggunakan kartu tani, dan petani kurang berminat dalam memanfaatkan kartu tani untuk kegiatan perbankan yang dilatarbelakangi minimnya pengalaman responden mengakses perbankan. Sementara itu, petani yang memiliki pengalaman bertani kurang dari 10 tahun cenderung mendukung program kartu tani dan mau mengikuti anjuran penyuluh. Pada umumnya petani tersebut sudah pernah mengakses bank sebelumnya, meskipun kurang berpengalaman dalam mengelola usaha tani.

Petani di Indonesia pada umumnya termasuk petani gurem dengan luas penguasaan dan penggunaan lahan relatif sempit, kurang dari 0,5 $\mathrm{Ha}$. Petani menggarap lahan baik lahan yang menjadi miliknya, lahan sewa, atau lahan bengkok yang dikelola dengan sistem bagi hasil. Petani yang tidak memiliki lahan, menjalankan usahataninya melalui bagi hasil, sewa, dan gadai (Susilowati 2013). Luas lahan garapan petani tidak begitu terkait dengan pelaksanaan program kartu tani, baik petani dengan luas lahan garapan sempit maupun luas, masingmasing mendapat bagian pupuk bersubsidi sesuai dengan luas lahannya sebagaimana sudah diusulkan melalui RDKK. 


\section{PELAKSANAAN PROGRAM KARTU TANI DI TINGKAT PETANI}

Mayoritas petani mengikuti arahan penyuluh dan mendukung program kartu tani karena mudahnya dalam menebus pupuk bersubsidi. Mayoritas petani menghadiri sosialisasi sebanyak 2-4 kali yang dilaksanakan oleh pemerintah baik di tingkat kabupaten melalui dinas serta pemerintah desa yang dibantu oleh Bank BRI maupun sosialisasi di tingkat kelompok yang biasa disampaikan melalui penyuluh lapangan dan ketua kelompok saat pertemuan kelompok. Materi sosialisasi yang disampaikan antara lain pemaparan program kartu tani, manfaat program, cara pembuatan dan penggunaan kartu tani serta pendataan petani.

Kelompok tani mempunyai berbagai peran dalam pelaksanaan program kartu tani, antara lain: pendataan anggota kelompok dan pendaftaran pembuatan kartu tani dengan cara pengumpulan fotocopy KTP, KK dan SPPT tanah; penyusunan RDKK (Rencana Definitif Kebutuhan Kelompok) untuk pengajuan pupuk bersubsidi sesuai dengan luas lahan; sosialisasi dan pengenalan program kartu tani; penebusan atau pembelian pupuk bersubsidi di pengecer.

Rencana definitif kebutuhan kelompok (RDKK) disusun oleh pengurus kelompok tani dibantu oleh penyuluh. Kelompok tani memberikan beberapa kebijakan dan menyediakan fasilitas untuk memudahkan anggota dalam menebus pupuk menggunakan kartu tani antara lain: 1) pengaktifan, pembelian dan penebusan pupuk diwakilkan kepada kelompok karena banyaknya petani usia lanjut yang mengalami kendala dalam mengakses bank serta banyak petani tidak memiliki kendaraan bermotor; 2) pendistribusian kartu tani belum merata sehingga kelompok membuat kebijakan untuk membantu anggota yang belum memperoleh kartu dengan meminjamkan kuota pupuk antar anggota kelompok dengan kesepakatan bersama; 3) peminjaman dana melalui kas kelompok karena banyak anggota tidak memiliki cukup biaya untuk membeli pupuk. Peran kelompok sangat membantu dan memudahkan petani dalam melaksanakan program kartu tani, khususnya untuk membeli pupuk, dan juga menjadikan kelompok menjadi lebih aktif.

Petani menilai terdapat perbedaan distribusi pupuk bersubsidi antara sebelum dengan setelah adanya kartu tani. Perbedaan ini dikarenakan dahulu pupuk dijual secara bebas, sehingga petani dapat membeli dimana saja bahkan bisa sampai luar daerah, dan pupuk ditebus menggunakan uang tunai atau langsung. Sebelum pelaksanaan program kartu tani, harga pupuk cenderung fluktuatif dikarenakan permainan pedagang, sekarang harga pupuk sesuai dengan HET (Harga Eceran Tertinggi) yang telah diatur pemerintah. Sebelum pelaksanaan program kartu tani terdapat banyak kasus terkait distribusi pupuk bersubsidi, antara lain berupa penyelewengan pupuk bersubsidi yang mengakibatkan kelangkaan pupuk dan waktu pendistribusian pupuk yang lama.

Dalam pembuatan dan pelaksanaan kartu tani masih ditemukan banyak kendala antara lain: 1) dilihat dari sisi pembuatan yaitu kesulitan mengajak petani untuk mengumpulkan fotocopy KTP dan SPPT; 2) dilihat dari sisi penggunaan yaitu petani mengalami kesulitan dalam penebusan/pembelian menggunakan kartu tani disebabkan petani harus aktivasi dan menabung terlebih dahulu ke bank dan membutuhkan banyak waktu dalam pembelian pupuk bersubsidi. Hal lain yang dikeluhkan petani adalah antrian yang lama jika berada di bank yang membuat petani mengurungkan niat untuk pergi ke bank.

\section{PENGETAHUAN PETANI TERHADAP PROGRAM KARTU TANI}

Pengetahuan petani terkait pelaksanaan program kartu tani dinilai berdasarkan pemahaman terhadap program kartu tani mencakup tujuan, ruang lingkup, struktur organisasi, manfaat, pedoman, dan cara penggunaan dari kartu tani. Skor tingkat pengetahuan yang diperoleh masing-masing petani menunjukkan bahwa tidak ada petani yang memiliki tingkat pengetahuan terkait program kartu tani dengan katagori tidak tahu (Tabel 2). Mayoritas petani di Kabupaten Semarang memiliki tingkat pengetahuan terhadap program kartu tani yang termasuk dalam kategori kurang tahu, terdiri atas 62 jiwa dan persentase $52 \%$. Hal ini disebabkan petani 
sudah pernah mengakses perbankan, dan adanya peran kelompok tani dan pendampingan penyuluh lapangan dalam meningkatkan pengetahuan petani dengan cara sosialisasi kartu tani secara kontinyu pada saat pertemuan rutin kelompok. Penelitian Suharyono (2016) mengungkapkan hal yang sama terkait pentingnya sosialisasi dalam mengenalkan suatu program. Melalui sosialisasi terjadi interaksi antara petani dengan instansi terkait yang dapat meningkatkan pengetahuan petani, sehingga tujuan program dapat tercapai.
TABEL 2. DISTRIBUSI RESPONDEN BERDASARKAN PENGETAHUAN PETANI TERHADAP PROGRAM KARTU TANI

\begin{tabular}{lccc}
\hline \multicolumn{1}{c}{ Katagori Pengetahuan Responden } & $\begin{array}{c}\text { Range Total } \\
\text { Skor }\end{array}$ & Jumlah & $\begin{array}{c}\text { Katagori Pengetahuan } \\
\text { Responden }\end{array}$ \\
\hline Tidak tahu & $25-57$ & 0 & 0 \\
Kurang tahu & $58-90$ & 62 & 52 \\
Tahu & $91-125$ & 58 & 48 \\
\hline & & 120 & 100 \\
\hline
\end{tabular}

Jika ditelaah lebih cermat berdasarkan rincian setiap indikator (Tabel3) maka dapat dilihat, bahwa terdapat beberapa aspek yang kurang diketahui petani.

TABEL 3. PERTANYAAN DAN DISTRIBUSI FREKUENSI RESPONDEN PER INDIKATOR DALAM VARIABEL PENGETAHUAN

\begin{tabular}{|c|c|c|c|c|c|c|}
\hline \multirow[b]{2}{*}{ No } & \multirow[b]{2}{*}{ Pertanyaan } & \multicolumn{5}{|c|}{ Distribusi frekuensi responden per skor (orang) } \\
\hline & & $\begin{array}{c}1 \\
\text { Sangat } \\
\text { Tidak Tahu }\end{array}$ & $\begin{array}{c}2 \\
\text { Tidak Tahu }\end{array}$ & $\begin{array}{c}3 \\
\text { Kurang } \\
\text { Tahu }\end{array}$ & $\begin{array}{c}4 \\
\text { Tahu }\end{array}$ & $\begin{array}{c}5 \\
\text { Sangat Tahu }\end{array}$ \\
\hline \multicolumn{7}{|c|}{ Aspek Tujuan } \\
\hline 1. & Program Kartu tani adalah terwujudnya distribusi pupuk bersubsidi sesuai dengan asas 6 tepat & 20 & 25 & 15 & 48 & 12 \\
\hline 2. & Program kartu tani sebagai pemberian layanan perbankan bagi petani di Jawa Tengah & 4 & 2 & 21 & 66 & 27 \\
\hline 3. & Program Kartu Tani sesuai dengan kebutuhan dan kondisi wilayah petani & 1 & 1 & 6 & 89 & 23 \\
\hline 4. & $\begin{array}{l}\text { Program Kartu Tani dapat terealisasi dengan baik apablia peran penyuluh dan kelompok saling } \\
\text { sinergis }\end{array}$ & 0 & 1 & 1 & 67 & 51 \\
\hline $\begin{array}{l}5 . \\
\text { Aspe }\end{array}$ & $\begin{array}{l}\text { Program Kartu Tani adalah pengawasan pupuk bersubsidi serta pendataan petani. } \\
\text { Ruang Lingkup }\end{array}$ & 0 & 1 & 11 & 80 & 28 \\
\hline 6. & Program Kartu Tani merupakan program pengelolaan distribusi pupuk bersubsidi bagi petani & 0 & 0 & 2 & 41 & 77 \\
\hline 7. & $\begin{array}{l}\text { Kartu debit BRI digunakan untuk membaca alokasi Pupuk Bersubsidi dan transaksi pembayaran } \\
\text { Pupuk Bersubsidi }\end{array}$ & 1 & 4 & 19 & 50 & 46 \\
\hline 8. & $\begin{array}{l}\text { Program Kartu Tani terintegrasi dengan aplikasi Sistem Informasi Manajemen Pangan Indonesia } \\
\text { (SIMPI) }\end{array}$ & 5 & 35 & 66 & 14 & 0 \\
\hline 9. & Program Kartu Tani merupakan program Pemerintah Pusat & 0 & 5 & 18 & 87 & 10 \\
\hline 10. & Alokasi pupuk bersubsidi berdasarkan peraturan daerah setempat & 23 & 32 & 29 & 30 & 6 \\
\hline \multicolumn{7}{|c|}{ Aspek Struktur Organisasi } \\
\hline 11. & $\begin{array}{l}\text { Subsidi Pupuk dalam Program Kartu Tani berasal dari rancangan RDKK (Rancangan Definitif } \\
\text { Kebutuhan Kelompok) }\end{array}$ & 20 & 26 & 26 & 32 & 16 \\
\hline 12. & Program Kartu Tani terlaksana atas bantuan Dinas Pertanian, Badan Penyuluhan dan Bank BRI & 0 & 0 & 9 & 70 & 41 \\
\hline \multicolumn{7}{|c|}{ Aspek Manfaat } \\
\hline 14. & Kartu tani memiliki manfaat yang sangat penting bagi bantuan permodalan untuk petani & 37 & 34 & 12 & 31 & 6 \\
\hline 15. & Kartu tani memudahkan petani dalam mengakses perbankan & 2 & 4 & 13 & 64 & 37 \\
\hline 16. & Kartu Tani memudahkan petani dalam membeli pupuk bersubsidi & 0 & 0 & 0 & 37 & 83 \\
\hline 17. & Kartu Tani memudahkan petani dalam menjual hasil panen & 83 & 24 & 7 & 6 & 0 \\
\hline \multicolumn{7}{|c|}{ Aspek Pedoman } \\
\hline 18. & Petani mengetahui pedoman usulan pembuatan kartu tani & 2 & 6 & 7 & 97 & 8 \\
\hline 20. & Pedoman pelaksanaan kartu tani telah disosialisasikan ke petani & 0 & 0 & 7 & 93 & 20 \\
\hline 21. & Pelaksanaan program kartu tani telah sesuai dengan pedoman yang berlaku & 1 & 4 & 17 & 91 & 7 \\
\hline \multicolumn{7}{|c|}{ Aspek Cara Penggunaan } \\
\hline 22. & Petani mengetahui cara penebusan pupuk bersubsidi menggunakan kartu tani & 0 & 1 & 7 & 67 & 45 \\
\hline 23. & Alokasi Pupuk bersubsidi tidak dapat diambil sekaligus & 6 & 13 & 23 & 64 & 14 \\
\hline 24. & $\begin{array}{l}\text { Pemilik kartu tani hanya dapat melakukan pengambilan alokasi pupuk bersubsidi sesuai dengan } \\
\text { waktu kebutuhan yang tertera }\end{array}$ & 5 & 14 & 16 & 78 & 7 \\
\hline
\end{tabular}

Berdasarkan Tabel 3 dapat diperoleh hasil bahwa ditinjau dari aspek tujuan kartu tani mayoritas petani mengetahui tujuan dari program, tetapi masih terdapat petani tidak mengetahui tujuan kartu tani perihal program kartu tani mendukung terwujudnya distribusi pupuk bersubsidi sesuai asas 6 tepat (poin 1) 
Hal tersebut disebabkan petani tidak memperhatikan penyampaian informasi penyuluh maupun instansi terkait dengan baik dan seksama.

Dilihat dari aspek ruang lingkup mayoritas petani mengetahui ruang lingkup program kartu tani, namun masih terdapat petani yang kurang mengerti khususnya perihal SIMPI (Sistem Informasi Pangan Indonesia) dan pengalokasian pupuk berdasarkan peraturan daerah. Hal ini dikarenakan petani hanya mengetahui bahwa pupuk bersubsidi diatur dan disusun oleh penyuluh serta cenderung acuh perihal alokasi pupuk bersubsidi.

Dilihat dari aspek struktur organisasi masih terdapat beberapa petani yang kurang mengerti khususnya perihal RDKK (Rencana Definitif Kebutuhan Kelompok) untuk permohonan pupuk bersubsidi. Hal ini terjadi karena para petani menyerahkan seluruh kewenangan permohonan subsidi pupuk kepada pegurus kelompok dan penyuluh. Anggota kelompok cenderung acuh perihal mekanisme permohonan pupuk subsidi dan menerima serta mengikuti keputusan pengurus kelompok.

Dilihat dari aspek manfaat mayoritas petani mengetahui kartu tani sebagai alat untuk menebus pupuk dan untuk akses kegiatan perbankan, namun masih terdapat petani yang belum mengetahui manfaat kartu tani sebagai bantuan permodalan dan penjualan hasil panen. Hal ini dikarenakan kurangnya perhatian petani dalam penyampaian informasi yang diberikan oleh penyuluh maupun instansi terkait. Khusus bantuan permodalan harapan awal pemerintah adalah dengan penggunaan kartu tani yang baik dan kemampuan berkelompok yang solid, petani melalui kelompok tani dapat mengusulkan bantuan permodalan kepada Bank BRI melalui KUR (Kredit Usaha Rakyat), tetapi fakta di lapangan masih terdapat kendala, khususnya di tingkat petani, sehingga bantuan permodalan belum dapat tersalurkan dengan baik. Untuk menjual hasil panen mayoritas petani di Kabupaten Semarang menjual secara langsung hasil panen dengan cara tebasan (padi) atau kepada tengkulak/pedagang. Khusus penjualan hasil panen harapan awal pemerintah adalah dengan penggunaan kartu tani, petani dapat menyalurkan hasil panennya kepada Bulog khususnya petani komoditas padi dan jagung. Akan tetapi kurangnya pemahaman dan mekanisme yang berbelit mengakibatkan banyak petani menjual secara langsung.

Dilihat dari aspek pedoman dan cara penggunaan kartu tani mayoritas petani mengetahui dan tidak terdapat kendala mengenai hal tersebut. Petani yang banyak mengetahui program kartu tani adalah pengurus kelompok tani, dan petani anggota kelompok yang memiliki pendidikan tinggi serta memiliki keinginan untuk mengawal program pemerintah; sedangkan petani yang tidak banyak perihal program kartu tani adalah petani anggota kelompok yang memiliki pendidikan rendah, mengikuti keputusan kelompok dan cenderung acuh terhadap program yang disampaikan. Pengetahuan petani terhadap program kartu tani sudah tergolong baik, tetapi pelu ditingkatkan khususnya pada aspek ruang lingkup, struktur organisasi dan manfaat program, dengan cara pendampingan yang kontinyu oleh penyuluh dan pihak terkait dalam pelaksanaan program kartu tani.

\section{EFEKTIVITAS PELAKSANAAN PROGRAM KARTU TANI}

Efektivitas pelaksanaan program kartu tani dilihat kesesuaian pelaksanaan dan penggunaan kartu tani dengan tujuan, yaitu terpenuhinya asas 6 tepat (jumlah, jenis, tempat, waktu, mutu, dan harga) dalam pendistribusian, pengendalian dan pengawasan pupuk bersubsidi.

TABEL 4. DISTRIBUSI RESPONDEN BERDASARKAN EFEKTIVITAS PELAKSANAAN PROGRAM KARTU TANI

\begin{tabular}{lrrr}
\hline $\begin{array}{c}\text { Kategori Efektivitas } \\
\text { Responden }\end{array}$ & Range Total Skor & $\begin{array}{r}\text { Jumlah } \\
\text { (Jiwa) }\end{array}$ & $\begin{array}{c}\text { Persentase } \\
(\%)\end{array}$ \\
\hline Tidak efektif & $18-41$ & 0 & 0 \\
Kurang efektif & $42-65$ & 7 & 6 \\
Efektif & $66-90$ & 113 & 94 \\
\hline & & 120 & 100 \\
\hline
\end{tabular}

Data pada Tabel 4 menunjukkan sebagian besar responden (94\%) mendapat perolehan skor efektifitas yang termasuk dalam katagori tinggi. Hal tersebut menandakan bahwa pelaksanaan program kartu tani di Kabupaten Semarang berjalan efektif. Artinya, pendistribusian, pengendalian dan 
pengawasan pupuk bersubsidi di Kabupaten Semarang

sudah memenuhi asas 6 tepat, sehingga

pendistribusian pupuk bersubsidi tepat sasaran sesuai

dengan penerimanya.

TABEL 5. PERTANYAAN DAN DISTRIBUSI FREKUENSI RESPONDEN PER INDIKATOR DALAM VARIABEL EFEKTIVITAS

\begin{tabular}{|c|c|c|c|c|c|c|}
\hline \multirow[b]{2}{*}{ No } & \multirow[b]{2}{*}{ Pertanyoan } & \multicolumn{5}{|c|}{ Distribusi frekuensi responden per skor (orang) } \\
\hline & & $\begin{array}{c}1 \\
\text { Sangat } \\
\text { Tidak Setuju }\end{array}$ & $\begin{array}{c}2 \\
\text { Tidak } \\
\text { Setuju }\end{array}$ & $\begin{array}{c}3 \\
\text { Netral }\end{array}$ & $\begin{array}{c}4 \\
\text { Setuju }\end{array}$ & $\begin{array}{c}5 \\
\text { Sangat } \\
\text { Setuju }\end{array}$ \\
\hline \multicolumn{7}{|c|}{ Aspek Tepat Jumlah } \\
\hline 1. & Alokasi pupuk bersubsidi pada kartu tani yang diperoleh sudah sesuai jumlah yang diusulkan dalam RDKK & 0 & 18 & 8 & 70 & 24 \\
\hline 2. & Jumlah pupuk bersubsidi yang diedarkan dapat mencukupi kebutuhan petani setiap musim tanam & 0 & 3 & 2 & 77 & 38 \\
\hline & $\begin{array}{l}\text { Dengan program Kartu Tani maka terwujudnya pendistribusian, pengendalian dan pengawasan pupuk bersubsidi } \\
\text { kepada para petani yang berhak }\end{array}$ & 0 & 1 & 0 & 74 & 45 \\
\hline & Program Kartu Tani sudah tepat sasaran & 0 & 8 & 10 & 81 & 21 \\
\hline \multicolumn{7}{|c|}{ Aspek Tepat Jenis } \\
\hline 5. & Alokasi pupuk bersubsidi pada kartu tani yang diperoleh sudah sesuai jenis yang diusulkan & 0 & 0 & 1 & 45 & 74 \\
\hline 6. & Jenis pupuk bersubsidi yang diedarkan selalu tersedia setiap musim tanam & 0 & 0 & 1 & 70 & 49 \\
\hline & Program Kartu Tani membantu petani dalam akses layanan perbankan. & 0 & 0 & 19 & 86 & 12 \\
\hline \multicolumn{7}{|c|}{ Aspek Tepat Tempat } \\
\hline 8. & Alokasi pupuk bersubsidi pada kartu tani yang diperoleh dapat ditebus sesuai dengan tempat / wilayah petani & 0 & 0 & 3 & 63 & 54 \\
\hline 9. & Fasilitas tempat penebusan pupuk sudah memadai & 0 & 8 & 2 & 77 & 33 \\
\hline & Akses ke tempat penebusan mudah dan bagus & 0 & 7 & 13 & 91 & 9 \\
\hline \multicolumn{7}{|c|}{ Aspek Tepat Waktu } \\
\hline 11. & Alokasi pupuk bersubsidi pada kartu tani yang diperoleh dapat ditebus sesuai dengan waktunya & 0 & 0 & 1 & 43 & 76 \\
\hline 12. & Pupuk bersubsidi yang diedarkan selalu tepat waktu dalam pendistribusian & 0 & 0 & 0 & 63 & 57 \\
\hline & Program Kartu Tani sudah dilaksanakan oleh pemerintah dengan baik & 0 & 0 & 2 & 81 & 37 \\
\hline \multicolumn{7}{|c|}{ Aspek Tepat Mutu } \\
\hline 14. & Alokasi pupuk bersubsidi pada kartu tani yang diperoleh sesuai dengan mutunya & 0 & 2 & 4 & 78 & 36 \\
\hline 15. & Pupuk bersubsidi yang diedarkan selalu tepat mutu setiap musim tanam dan bukan pupuk palsu & 0 & 1 & 1 & 62 & 56 \\
\hline 16. & Program Kartu Tani akan memberikan manfaat bagi petani & 0 & 6 & 6 & 92 & 16 \\
\hline \multicolumn{7}{|c|}{ Aspek Tepat Harga } \\
\hline 17. & Alokasi pupuk bersubsidi pada kartu tani yang diperoleh sesuai dengan harga eceran tetap (HET) & 0 & 0 & 1 & 36 & 83 \\
\hline & Ada pengawasan harga pupuk bersubsidi yang kontinyu dalam program kartu tani. & 0 & 1 & 2 & 67 & 50 \\
\hline
\end{tabular}

Dilihat dari aspek tepat jumlah dan tepat jenis, pupuk yang didapatkan mayoritas petani sudah sesuai dengan jumlah dan jenis yang diusulkan di RDKK, serta pupuk yang dijual-belikan selalu tersedia setiap musim tanam (Tabel 5). Namun demikian, petani yang memiliki pengetahuan rendah cenderung tidak setuju terhadap alokasi yang diberikan, karena menganggap pupuk subsidi yang didapatkan terlalu sedikit dan masih memilki pemikiran kuno (menganggap pupuk subsidi harus banyak agar produksi baik). Dengan adanya program kartu tani, petani semakin tahu cara memupuk yang baik, sesuai dengan anjuran, tidak berlebih dan sesuai dengan luas lahan. Program sudah tepat sasaran, karena penerima subisidi pupuk adalah petani yang berhak mendapatkannya. Namun, masih terdapat petani yang tidak mendapatkan jumlah pupuk yang tepat sesuai dengan luas lahan yang digarap. Hal ini dikarenakan kesalahan teknis pada saat input data yang diajukan ke SIMPI dan minimnya alokasi pupuk bersubsidi. Masalah ini diatasi dengan pengusulan RDKK tambahan untuk para petani yang masih kekurangan, dan penambahan alokasi pupuk bersubsidi. Jumlah yang diedarkan pengecer juga dapat memenuhi permintaan petani karena dengan adanya program kartu tani pengecer harus menyediakan jumlah yang pas untuk beberapa minggu ke depan dengan jenis pupuk yang lengkap. Adanya kartu tani membantu petani mengakses perbankan khususnya untuk menabung dan menebus pupuk bersubsidi.

Ditinjau dari tepat tempat mayoritas petani menyatakan bahwa tempat menebus pupuk dekat dengan tempat tinggal, akses yang mudah ke pengecer dikarenakan infrastruktur dan transportasi yang memadai serta informasi yang disampaikan dan bagusnya fasilitas yang diberikan pengecer 
(pengiriman pupuk secara langsung ke petani) membuat petani paham terhadap program kartu tani. Ditinjau dari tepat waktu mayoritas petani menyatakan bahwa dalam pembelian pupuk tidak memerlukan waktu yang lama. Demikian juga dalam menunggu distribusi pupuk. Ditinjau dari tepat mutu mayoritas petani menyatakan bahwa mutu pupuk yang diperoleh sudah sesuai dengan yang diharapkan, walaupun masih jauh jika dibandingkan dengan pupuk non subsidi.

Ditinjau dari segi harga mayoritas petani menyatakan bahwa harga pupuk yang dijual ditingkat pengecer sudah sesuai dengan HET. Fakta di lapangan menunjukkan tidak terjadi permainan harga karena adanya pengawasan harga pupuk oleh aparat dan pemerintah. Harga pupuk ditingkat petani terdapat tambahan biaya untuk kas kelompok, biaya administrasi dan biaya angkut pupuk yang sudah disepakati antar anggota kelompok. Hal ini selaras dengan pendapat Ardiyanto (2013) yang menyatakan bahwa permintaan pupuk bersubsidi yang tinggi memunculkan biaya proses pemasaran pupuk misalnya transport, biaya bongkar muat, dan lain-lain.

Berdasarkan hasil tersebut dapat disimpulkan bahwa dibandingkan dengan tahun sebelumnya pendistribusian, pengendalian dan pengawasan pupuk bersubsidi menggunakan kartu tani jauh lebih efektif dibandingkan secara langsung dikarenakan sudah sesuai asas 6 tepat dan sesuai dengan harapan petani. Walaupun masih terdapat beberapa petani yang menyatakan netral atau kurang tepat pada aspek tepat jumlah khususnya perihal alokasi pupuk sesuai jumlah yang diusulkan RDKK, tepat sasaran; tepat jenis khususnya program kartu tani membantu petani dalam akses layanan perbankan; serta tepat tempat, khususnya terkait dengan kemudahan mengakses tempat penebusan pupuk bersubsidi. Hal tersebut dikarenakan pengetahuan yang minim dan acuh atau kurang berminat untuk mengikuti program pemerintah.

Berbeda dengan hasil penelitian Sularno (2016) terkait pendistribusian pupuk secara langsung, yang masih menemukan beberapa masalah, yaitu terjadinya kelangkaan pupuk, permainan harga, dan keterlambatan pengiriman yang disebabkan minimnya jumlah pupuk subsidi dan lemahnya pengawasan pengedaran pupuk dari pemerintah. Adanya program kartu tani mampu meningkatkan pengendalian penggunaan pupuk sesuai dengan luas lahan dan anjuran penyuluh. Petani yang mendapatkan pupuk tidak sesuai dengan luasan lahan dapat dibantu dengan pengajuan RDKK tambahan serta penambahan alokasi pupuk. Terdapat pengawasan pengedaran pupuk subsidi oleh pemerintah melalui KP3 (Komisi Pengawasan Pupuk dan Pestisida) bekerjasama dengan aparat penegak hukum sehingga pupuk benar-benar sesuai didistribusikan kepada petani yang membutuhkan.

\section{HUBUNGAN PENGETAHUAN PETANI DENGAN EFEKTIVITAS PELAKSANAAN PROGRAM KARTU TANI}

Hasil Uji Korelasi Rank Spearman antara pengetahuan petani terhadap program kartu tani dengan efektivitas pelaksanaan program kartu tani sebagaimana ditampilkan pada Tabel 6, menunjukkan bahwa pelaksanaan program kartu tani di Kabupaten Semarang akan lebih efektif jika petani mempunyai pengetahuan yang lebih komprehensif terkait program kartu tani.

TABEL 6. HUBUNGAN PENGETAHUAN DAN EFEKTIVITAS PELAKSANAAN PROGRAM

\begin{tabular}{ccc}
\hline \multirow{2}{*}{ Variabel $(X)$} & \multicolumn{3}{c}{ Efektivitas Pelaksanaan Program Kartu Tani $(Y)$} \\
\cline { 2 - 3 } & Korelasi $(r)$ & Sig. (2-tailed) \\
\hline Tingkat Pengetahuan Petani & 0,568 & 0,000 \\
\hline
\end{tabular}

Hasil analisis data pada Tabel 6 menunjukkan bahwa nilai koefisien korelasi (r) sebesar 0,568, dan nilai Sig. (2-tailed) 0,000 yang artinya terdapat hubungan yang kuat dan sangat signifikan antara tingkat pengetahuan petani dengan efektivitas pelaksanaan program kartu tani. Hal tersebut menunjukkan bahwa semakin tinggi tingkat pengetahuan petani terhadap program kartu tani maka semakin tinggi efektivitas pelaksanaan program kartu tani. Hal senada ditemukan dalam penelitian Abidin (2015) terdapatnya hubungan yang positif antara aspek pengetahuan dengan pencapaian tujuan penyuluhan, artinya semakin baik pengetahuan petani maka semakin tercapai tujuan penyuluhan. 
Meningkatnya pengetahuan petani khususnya pada aspek tujuan, manfaat, pedoman dan cara penggunaan kartu tani akan meningkatkan penggunaan kartu tani dalam penebusan dan pendstribusian pupuk bersubsidi sesuai dengan asas 6 tepat (jenis, jumlah, tempat, waktu, mutu, harga) sehingga dapat meningkatkan efektivitas pelaksanaan program kartu tani.

Adanya hubungan yang signifikan antara tingkat pengetahuan petani dengan efektivitas pelaksanaan program kartu tani dikarenakan adanya peran aktif kelompok tani dalam memberikan informasi dan bantuan dalam pelaksanaan program kartu tani. Bantuan tersebut diberikan dalam bentuk pendataan anggota kelompok dan pendaftaran pembuatan kartu tani; penyusunan RDKK (Rencana Definitif Kebutuhan Kelompok) untuk pengajuan pupuk bersubsidi sesuai dengan luas lahan; sosialisasi dan pengenalan program kartu tani; penebusan atau pembelian pupuk bersubsidi di pengecer. Dengan demikian petani dapat merasakan manfaat program dengan baik dan sesuai dengan tujuan.

Meningkatnya pengetahuan petani melalui sosialisasi yang diperoleh petani dari penyuluh, dinas terkait dan Bank BRI membuat petani semakin tahu terhadap program dan membuat petani melaksanakan program dengan cara menggunakan kartu tani untuk menebus pupuk bersubsidi tanpa adannya paksaan. Hal ini diperkuat pendapat Pratama (2016) yang menyatakan bahwa peran kelompok tani yang dibantu penyuluh untuk membuat kelompok menjadi kelas belajar dan wahana kerjasama sangat berpengaruh dalam membantu petani melaksanaan usahataninya sehingga keberhasilan dapat dicapai. Tingkat pengetahuan petani sangat berpengaruh dalam meningkatkan efektivitas pelaksanaan suatu program. Informasi yang diperoleh dari sosialisasi program kartu tani yang telah dilaksanakan oleh penyuluh, dinas terkait dan Bank BRI membuat petani menjadi sadar akan manfaat program dan petani bersedia melaksanakan program tanpa adanya tekanan atau ketegangan. Berjalannya program dengan penerimaan dan pelaksanaan secara dengan baik oleh petani dapat meningkatkan efektivitas suatu program.

\section{KESIMPULAN}

Mayoritas petani mengikuti dan mendukung adanya program kartu tani dikarenakan mudahnya dalam menebus pupuk bersubsidi. Program kartu tani dilaksanakan petani melalui kelompok tani mengikuti arahan penyuluh mulai pengusulan, penerbitan sampai penebusan pupuk bersubsidi. Mayoritas petani memiliki pengetahuan terhadap program kartu tani yang tergolong kategori kurang tahu. Efektivitas pelaksanaan program kartu tani di Kabupaten Semarang tergolong dalam kategori efektif. Hal tersebut menandakan pendistribusian pupuk bersubsidi tepat sasaran sesuai dengan petani yang berhak menerima. Terdapat hubungan yang kuat dan sangat signifikan antara tingkat pengetahuan petani dengan efektivitas pelaksanaan program kartu tani. Semakin tinggi pengetahuan petani terhadap berbagai aspek terkait program, maka semakin tinggi pula kesadaran petani terhadap manfaat program. Sehingga bersedia menerima dan menjalankan program tanpa tekanan.

Berdasarkan hasil temuan diatas disarankan bahwa pelaksanaan program kartu tani di Kabupaten Semarang berjalan efektif sehingga perlu disebarluaskan karena memiliki banyak potensi dalam meningkatkan kemampuan petani khususnya terkait erat dengan pengetahuan dalam mengakses dunia perbankan dan pupuk bersubsidi pemerintah. Meskipun saat ini masih banyak ditemukan banyak kendala yang dihadapi sehingga sosialisasi perihal kartu tani perlu diperkuat kembali khusunya perihal bantuan akses permodalan dari Bank BRI melalui kartu tani, dan penjualan hasil panen menggunakan kartu tani. Dalam pelaksanaan program kartu tani kedepannya perlu adanya evaluasi, pengawasan dan pelaksanaan khsusnya pendampingan penggunaan kartu tani oleh petani secara mandiri agar kedepannya dapat menggunakan kartu tani dengan lebih baik lagi dan juga harus didukung oleh lembaga terkait agar pelaksanaan kartu tani dapat berjalan lebih efektif.

\section{DAFTAR PUSTAKA}

Abidin, N. I., Rosnita., dan Yulida, R. (2015). Efektivitas Media Penyuluhan yang Diberikan Kepada Petani Karet (Hevea brasiliensis) di Desa 
Gunung Bungsu kecamatan XIII Koto Kampar (Studi Kasus Penyuluhan Pengendalian Jamur Akar Putih).Jurnal Online Mahasiswa Faperta, 2(2), 1-14.

Ardiyanto, W., dan Santoso, P. B. (2013). Kajian Pupuk Bersubsidi di Pekalongan (Studi Kasus di Kecamatan Kesesi). Diponegoro : Journal Of Economics, 2(3), 1-15.

Arisandi, N. W. W., Sudarma, I. M., dan Rantau, I. K. (2016). Efektivitas Distribusi Subsidi Pupuk Organik dan Dampaknya terhadap Pendapatan Usahatani Padi Sawah di Subak Sungsang Desa Tibubiu Kabupaten Tabanan. Jurnal Agribisnis dan Agrowisata, 5(1), 1-10.

Biro Infrastruktur dan Sumber Daya Alam Provinsi Jawa Tengah.(2016). Petunjuk Praktis Penggunaan Kartu Tani Melalui Sistem Informasi Pertanian Indonesia (SINPI) Di Jawa Tengah.Retrieved from http://www.biroinfrasda.jatengprov.go. id.

Kementrian Pertanian. (2017). Petunjuk Pelaksanaan Penyediaan dan Penyaluran Pupuk Bersubsidi TA. 2018. Jakarta: Direktorat Jendral Prasarana dan Sarana Pertanian Kementrian Pertanian.

Moko, K. W., Suwarto., dan Utami, B. W. (2017). Presepsi Petani Terhadap Program Kartu Tani di Kecamatan Kaijambe Kabupaten Sragen. Jurnal Caraka Tani, 32(1), 10-14.

Nirzalin., dan Maliati, N. 2017. Produktivitas Pertanian dan Involusi Kesejahteraan Petani (Studi Kasus di Meunasah Pinto Aceh Utara). Jurnal Sosiologi Pedesaan, 5(2), 106-119.

Perarturan Mentri Perdagangan Nomor 15. (2013). Pengadaan dan Penyaluran Pupuk Bersubsidi untuk Sektor Pertanian. Jakarta: Kementrian Perdagangan

Pratama, B. P., Sayamar, E., dan Tety, E. (2016). Peran Kelompok Tani dalam Memingkatkan Pendapatan Petani Swadaya Kelapa Sawit di Desa Bukit Lingkar Kecamatan Batang Cenaku Kabupaten Indragiri Hulu. Jurnal Faperta, 3(2), 1-12.

Rachman, B., and Sudaryanto,T. (2010). Impacts and Future Perspectives of Fertilizer Policy In Indonesia. Journal Food Fertilizer and Technology, 11(1), 93-104.

Rangkuti, S. (2012).Efektivitas Pendistribusian Pupuk Bersubsidi di Kabupaten Deli Serdang (Studi Kasus di Kecamatan Hamparan Perak). Jurnal Administrasi Publik, 2(2), 287-317.

Sarwono, J., dan Salim, H. N. (2016). ProsedurProsedur Populer Statistik untuk Analisis Data Riset Skripsi. Yogyakarta : Penerbit Gava Media,

Siregar, S. (2017).Statistik Parametrik untuk Penelitian Kuantitatif. Jakarta: PT. Bumi Aksara.
Suharyanto.,Rinaldi, J., Arya, N. N., dan Mahaputra, K. (2017). Faktor - Faktor yang Mempengaruhi Persepsi Petani Terhadap Kebijakan Perlindungan Lahan Pertanian Pangan Berkelanjutan di Provinsi Bali. Jurnal Pengkajian dan Pengembangan Teknologi Pertanian, 20(2), 111-124.

Suharyon., dan Busyra, B. S. (2016). Kinerja Kelompok Tani dalam Sistem Usahatani Padi Lahan Sub Optimal dan Metode Pemberdayaan (Studi Kasus Pada Kegiatan Padi Sawah di Lahan Sub Optimal Kabupaten Tanjung Jabung Timur Jambi). Jurnal Penelitian Universitas Jambi Seri Humaniora, 18(1), 78-85.

Sularno., Irawan, B., dan Handayani, N. (2016). Analisis Pelaksanaan Kebijakan dan Distribusi Pupuk Bersubsidi di Kabupaten Karawang Jawa Barat. Jurnal Agrosains dan Teknologi, 1(2), 74-87.

Susila, W. R. (2010). Kebijakan Subsidi Pupuk : Ditinjau Kembali. Jurnal Litbang Pertanian, 29(2), 43 49

Susilowati, S. H., dan Maulana, M. (2012). Luas Lahan Usahatani dan Kesejahteraan Petani: Eksistensi Petani Gurem dan Urgensi Kebijakan Reforma Agraria. Jurnal Analisis Kebijakan Pertanian, 10(1), 17-30.

Widarti, S., Kurniawan, H.M., dan Simpuk, S. (2016).Analisis Pemasaran Pupuk Bersubsidi Tanaman Pangan di Kecamatan Sanggau Ledo Kabupaten Bengkayang. Jurnal Agrosains, 2(13), 9-13.

Yuliani, F. (2015). Efektivitas Implementasi Kebijakan Pupuk Subsidi pada Tanaman Pangan di Kabupaten Rokan Hilir. Jurnal Spirit Publik.1(10), 133-162. 